\title{
Adhesion and Fitness in the Bean Phyllosphere and Transmission to Seed of Xanthomonas fuscans subsp. fuscans
}

\author{
A. Darsonval, A. Darrasse, K. Durand, C. Bureau, S. Cesbron, and M.-A. Jacques \\ UMR077 PaVé, INRA, 42, rue George Morel, F-49071 Beaucouzé, France \\ Submitted 13 October 2008. Accepted 23 February 2009.
}

\begin{abstract}
Deciphering the mechanisms enabling plant-pathogenic bacteria to disperse, colonize, and survive on their hosts provides the necessary basis to set up new control methods. We evaluated the role of bacterial attachment and biofilm formation in host colonization processes for Xanthomonas fuscans subsp. fuscans on its host. This bacterium is responsible for the common bacterial blight of bean (Phaseolus vulgaris), a seedborne disease. The five adhesin genes (pilA, fhab, xadA1, xadA2, and yapH) identified in X. fuscans subsp. fuscans CFBP4834-R strain were mutated. All mutants were altered in their abilities to adhere to polypropylene or seed. PilA was involved in adhesion and transmission to seed, and mutation of pilA led to lower pathogenicity on bean. YapH was required for adhesion to seed, leaves, and abiotic surfaces but not for in planta transmission to seed or aggressiveness on leaves. Transmission to seed through floral structures did not require any of the known adhesins. Conversely, all mutants tested, except in $y a p H$, were altered in their vascular transmission to seed. In conclusion, we showed that adhesins are implicated in the various processes leading to host phyllosphere colonization and transmission to seed by plant-pathogenic bacteria.
\end{abstract}

Adhesion to host tissues is essential for successful infection by many microbial pathogens (Cao et al. 2001). The role of adhesion in virulence was demonstrated for plant pathogens (Astua-Monge et al. 2005; Feil et al. 2007; Matthysse and McMahan 1998; Ojanen-Reuhs et al. 1997; Rosenblueth and Martinez-Romero 2006) and animal bacterial pathogens (Barak et al. 2005; Gorski et al. 2003). The bacterial surface structures important for adhesion cover a broad group of fimbrial and nonfimbrial structures commonly known as adhesins (Barnhart and Chapman 2006; Hultgren et al. 1993; Klemm and Schembri 2000; Latasa et al. 2006). The fimbrial proteins include the type IV pili that deserve much interest (Craig et al. 2004). The type IV pili are polymeric assemblies of the protein pilin expressed by many gram-negative bacteria (Craig et al. 2004; Pizarro-Cerda and Cossart 2006). Unlike other types of pili, type IV pili not only participate in adhesion to host cells (Carbonnelle et al. 2006; Finlay and Falkow 1997; Mattick 2002; Tobe and Sasakawa 2002) but are also involved in a sur-

Corresponding author: M.-A. Jacques; Telephone: (33)-241-22-57-07; Fax: (33)-241-22-57-05; E-mail: Marie-Agnes.Jacques@ angers.inra.fr

* The $\boldsymbol{e}$-Xtra logo stands for "electronic extra" and indicates that a supplementary figure is published online. prisingly high number of functions (Merz et al. 2000), including bacterial aggregation, microcolony formation, and more complex biological functions such as DNA transformation and a form of surface translocation known as twitching motility (Kaiser 2007; Merz et al. 2000). The nonfimbrial adhesins are widely represented in $\alpha-, \beta$ - and $\gamma$-proteobacteria and contain different classes of proteins implied in bacterial attachment (Gerlach and Hensel 2007; Pizarro-Cerda and Cossart 2006). These proteins belong to the autotransporter family containing the trimeric autotransporters (for example, XadA and YadA proteins) (Cotter et al. 2005; Koretke et al. 2006) and to the two-partner secretion system as do filamentous hemagglutinin (for example, FhaB and YapH) (Mazar and Cotter 2006).

Sequenced genomes of plant-pathogenic xanthomonads (da Silva et al. 2002; Lee et al. 2005; Thieme et al. 2005) contain many genes coding surface adhesion structures, and comparative genomic studies suggested that they may play key roles in pathogenicity of strains on plants (da Silva et al. 2002). Xanthomonas citri subsp. citri and X. campestris pv. campestris have genes for type IV fimbrial pili for several proteins which could act as nonfimbrial adhesins (Astua-Monge et al. 2005; Thieme et al. 2005), such as homologs of the Yersinia proteins YapH and YadA (Hoiczyk et al. 2000) and for other filamentous hemagglutinin proteins (Astua-Monge et al. 2005). YadA mediates adherence to epithelial cells and autoagglutination (Hoiczyk et al. 2000). Homologs of YadA have been found in several plant- and animal-pathogenic bacteria (Nummelin et al. 2004) (e.g., in X. oryzae pv. oryzae, where XadA was shown to play a role of virulence factor) (Ray et al. 2002). Retractile pili of Pseudomonas syringae pv. tomato DC3000 had no apparent effect on pathogenicity but enhanced tolerance to environmental conditions such as exposure to UV light (Roine et al. 1998). Furthermore, homologs of filamentous hemagglutinin are also present in the plant pathogens Erwinia chrysanthemi (Kim et al. 1998) and Xylella fastidiosa, and their involvement in attachment and virulence has been demonstrated (Feil et al. 2007; Guilhabert and Kirkpatrick 2005; Rojas et al. 2002). The presence of numerous genes coding for surface structures in xanthomonad genomes may indicate a general importance of these proteins in the xanthomonad lifestyle. In natural settings, bacteria prefer a sedentary lifestyle in communities to a nomadic existence (Costerton et al. 1999; Danhorn and Fuqua 2007; O'Toole et al. 2000; West et al. 2006). Aggregation followed by biofilm formation is a strategy used by $X$. fuscans subsp. fuscans during colonization of bean phyllosphere for its protection from stresses and maintenance of inoculum reservoirs (Jacques et al. 2005).

Seed are the carriers of numerous plant pathogens. Seedborne bacterial plant pathogens are of particular concern because, 
unlike seedborne fungi, strategies for the management of bacterial diseases are very limited given the rare and antiquated chemical options available. X. fuscans subsp. fuscans (Schaad et al. 2005) and $X$. axonopodis pv. phaseoli (Vauterin et al. 1995, 2000) are causal agents of common bacterial blight of bean (Phaseolus vulgaris L), a seedborne disease (Vidaver 1993). These pathogens are transmitted to seed during cultivation of mother plants. Transmission of pathogens to seed has been reported to occur through three pathways. i) Seed can be internally contaminated via the host xylem, as occurs for virus transmission, some fungi and other bacteria. This usually results in the invasion of seed through the hilum. ii) Seed may also become infested via the pistil, where bacteria move from the stigma through the stylar tissues down to the embryo. Finally, iii) an external contamination of seed occurs via fruit as a consequence of contact of the seed with fruit tissue showing symptoms, or at harvest and during threshing with residues carrying large bacterial populations (Maude 1996). Although there is accumulating data concerning plant-pathogen interactions during vegetative growth, the interactions of bacterial pathogens with reproductive organs have not yet received much attention and, therefore, almost nothing is known of the molecular mechanisms underlying the transmission of bacterial pathogens to seed. We recently showed that the type III secretion system (T3SS), which is a major pathogenicity determinant of plant-pathogenic bacteria (Gurlebeck et al. 2006; Puhler et al. 2004), is strongly involved in the bean colonization of seed by X. fuscans subsp. fuscans (Darsonval et al. 2008). Unlike the wild-type strain, strains with mutations in T3SS regulatory and structural genes are not transmitted to seed by vascular pathway. Transmission to seed by floral structures remains possible but with a low efficiency for both types of mutants (Darsonval et al. 2008).

The intent of the present study was to investigate the role of fimbrial and nonfimbrial proteins of $X$. fuscans subsp. fuscans in phyllosphere (i.e., the environment of leaf surfaces) (Hirano and Upper 2000) colonization and transmission to the seed. Here, we report the identification and the characterization of one fimbrial and four nonfimbrial proteins in X. fuscans subsp. fuscans CFBP4834-R and their role in in vitro adhesion and

Table 1. Polymerase chain reaction (PCR) primers used in this study to construct and validate mutations in pilA, fhaB, $x a d A 1$, $x a d A 2$, and $y a p H$ of Xanthomonas fuscans subsp. fuscans CFBP4834-R

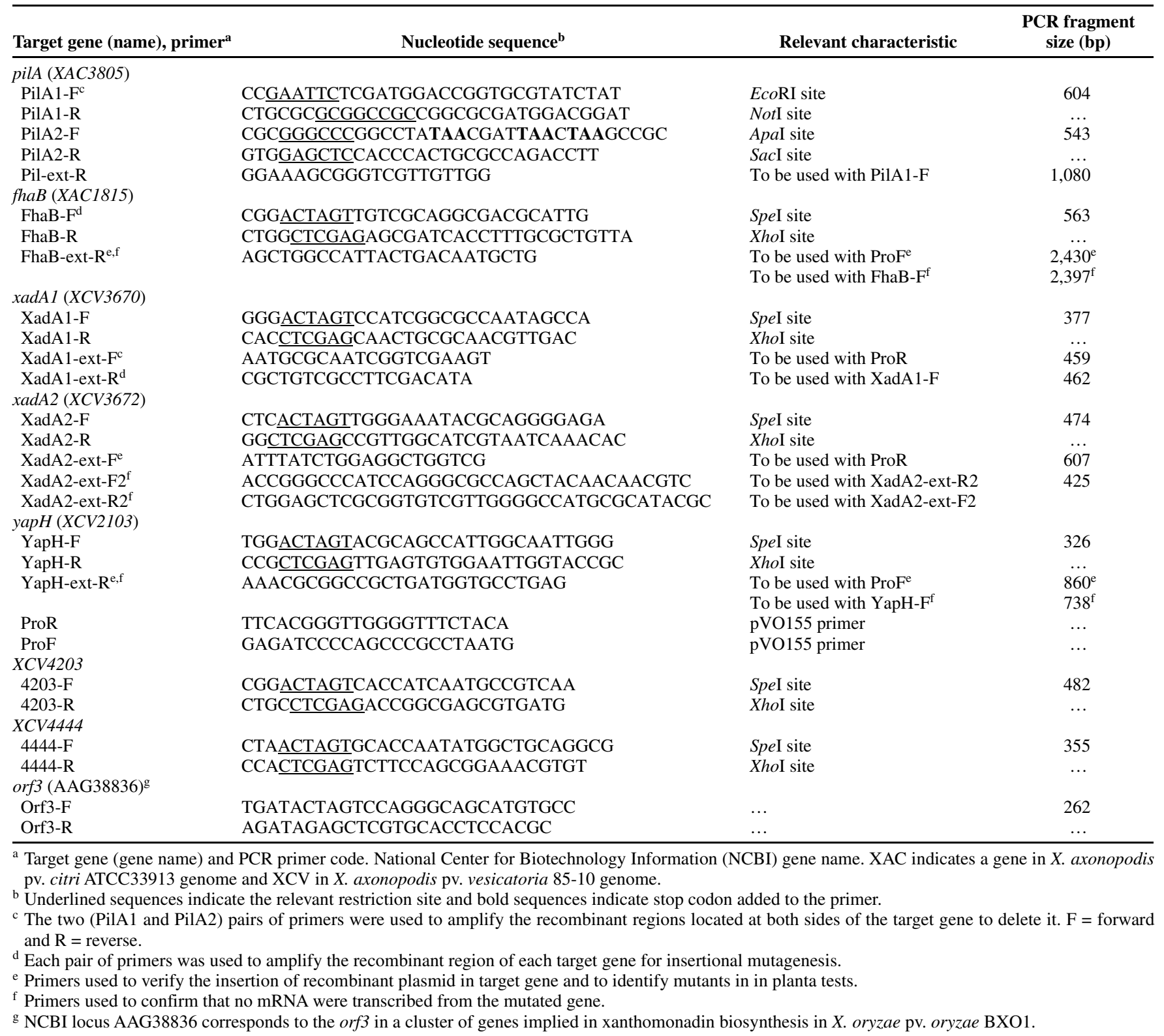


biofilm formation. We also compared their individual contribution to CFBP4834-R behavior during bean asymptomatic colonization of leaves and transmission to seed.

\section{RESULTS}

Five genes coding adhesins were identified and disrupted in X. fuscans subsp. fuscans.

Among adhesins that have been previously identified in xanthomonads (da Silva et al. 2002; Lee et al. 2005; Qian et al. 2005; Thieme et al. 2005), homologues of pilA (XAC3805), fhaB (XAC1815), xadA1 (XCV3670), xadA2 (XCV3672), and yapH (XCV2103) genes were detected by polymerase chain reaction (PCR) with specific primers (Table 1) in $X$. fuscans subsp. fuscans CFBP4834-R. The nucleotide sequences of the PCR fragments confirmed the identity of the target genes (data not shown). Mutation of the pilA resulted in a deletion of 108 nucleotides from the 268-bp position. Mutation of the other genes resulted in an insertion of the pVO155 in the recombining sequence by simple crossing-over. PCR amplifications using specific primer sets (Table 1) confirmed that pVO155 unique insertions were at the correct positions in mutated strains. Southern blot hybridizations confirmed the single plasmid insertion event. As an alternative to complementation of the mutations, the absence of polar effects of the mutations on downstream genes was confirmed by in silico analysis. For pilA, insertion of a stop codon avoided synthesis of a hybrid protein with the downstream gene. Based on X. citri subsp. citri 306 and X. axonopodis pv. vesicatoria 85-10 genomes, no polar effects were expected for mutation in $y a p H$ because the downstream gene is in the opposite transcription orientation. For the other three nonfimbrial adhesin genes, sizes of the intergenic sequences downstream of the target genes are longer than 100 bp, a sufficient length to avoid operon-type regulation. This organization is conserved in the CFBP4834-R genome (unpublished data). Furthermore, the in vitro phenotype changes of each fimbrial and nonfimbrial mutant were reproducible for three independent constructions per target gene. This ensures

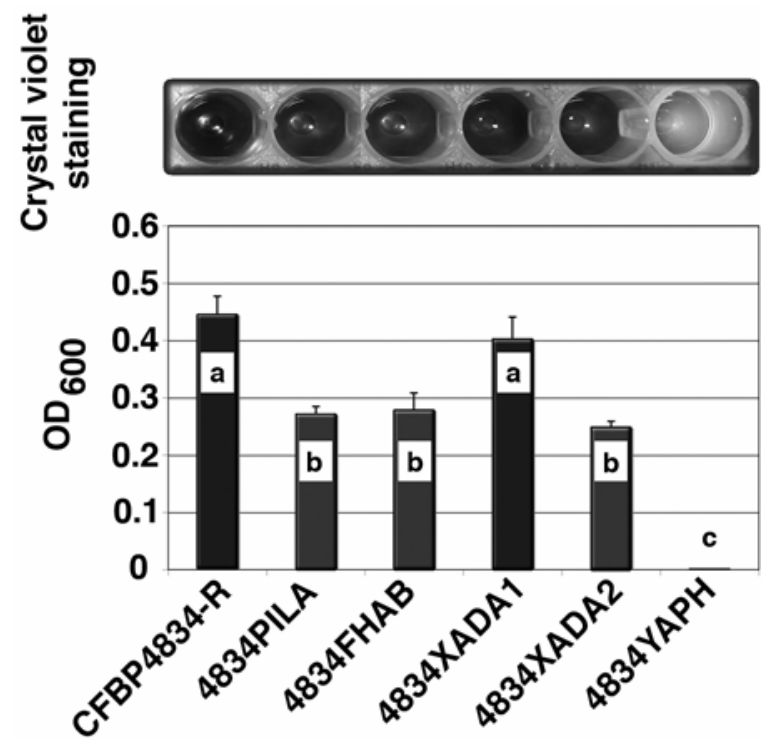

Fig. 1. Quantification of adhesion of Xanthomonas fuscans subsp. fuscans CFB4834-R and 4834PILA, 4834FHAB, 4834XADA1, 4834XADA2, and 4834YAPH mutants on polypropylene microtiter plates. Crystal violetstained, surface-attached cells were quantified by solubilizing the dye in ethanol and determination of the absorbance at $600 \mathrm{~nm}$. Error bars represent the standard deviation. Different letters refers to significantly different values based on a Mann-Whitney test. Three repetitions were monitored with similar results. that phenotype changes were due to site-directed mutagenesis and not to secondary mutations in the genome.

Growth rates of the wild-type CFBP4834-R and of every strain mutated in each adhesin gene were similar in $10 \%$ general medium, indicating that mutations did not impair the in vitro growth of the corresponding strain (data not shown). Furthermore, all constructions were stable both in vitro and in planta because no reversions were observed in vitro after 54 generations without selection pressure. Population sizes of each mutant enumerated from leaf samples on nonselective medium were not significantly $(P>0.05)$ higher than those enumerated on selective medium. The reverse-transcription (RT)-PCR confirmed that no mRNAs were transcribed from the disrupted genes in strains with mutations in fhaB, xadAl, $x a d A 2$, and yapH (Supplementary Fig. 1).

\section{Mutation in yapH suppressed adhesion \\ to abiotic and biotic surfaces and biofilm formation in $X$. fuscans subsp. fuscans CFBP4834-R.}

The crystal violet $(\mathrm{CV})$ incorporation assay revealed that 4834YAPH mutant was totally impaired in adhesion to polypropylene (PP) surface, a relatively hydrophobic surface (Fig. $1)$. The capacities of adhesion to PP were also significantly $(P<$ $0.05)$ decreased for three other mutants: 4834PILA, 4834FHAB, and 4834XADA2. In contrast, the mutant 4834XADA1 did not show any significant $(P>0.05)$ differences in adhesion to PP compared with the wild type. According to Yap and associates (2005), biofilms are defined as aggregates of cells around the edge of the culture tube at the airliquid surface interface and pellicles as thick aggregates of cells on the culture surface. Because biofilm and pellicle formations were never visible for cultures in PP plates, we modified a method developed by Yap and associates (2005) for Erwinia chrysanthemi to look for such formations in our strains. Briefly, this method is based on a stationary culture in a rich liquid medium in glass tubes. We added a step of biofilm coloration with CV. No pellicles were visible for any strains. Biofilm formation was altered only for 4834YAPH mutant compared with the wild type with a quasi absence of biofilm formation for this mutant (Fig. 2).

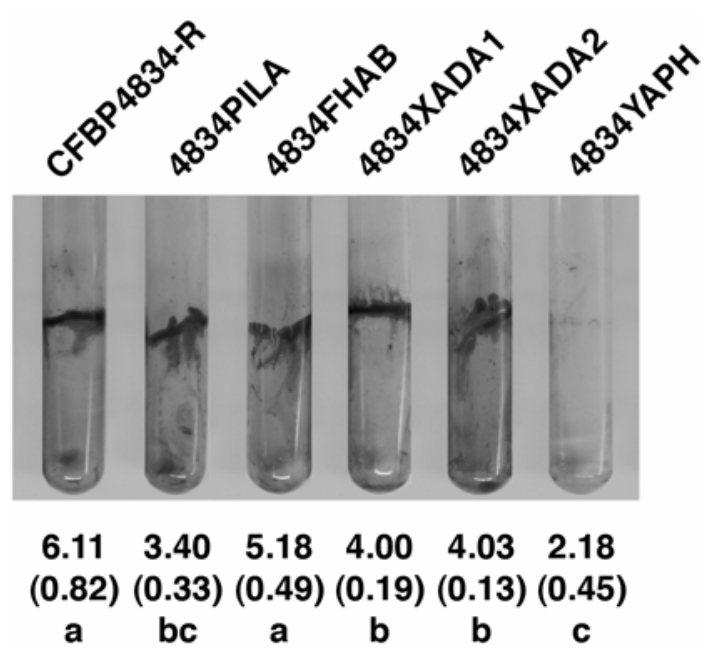

Fig. 2. Observation of in vitro biofilm formation by Xanthomonas fuscans subsp. fuscans CFB4834-R and 4834PILA, 4834FHAB, 4834XADA1, 4834XADA2, and 4834YAPH mutants. Biofilms adherent to the glass tubes were stained with crystal violet after 7 days of stationary culture at $28^{\circ} \mathrm{C}$ in SOB + glycerol. Below tubes, the first value refers to the mean amount (three repetitions) of crystal violet that stayed on sides of the tubes. It is followed by the standard error of the mean. Different letters indicate that amounts of crystal violet are significantly $(P<0.05)$ different on the basis of the Mann-Whitney test. 
Adhesion capacities on biotic surfaces were significantly altered for the five mutants compared with the wild type (Fig. 3 ). Adhesion to bean seed was evaluated after $25 \mathrm{~min}$ and $2 \mathrm{~h}$ of contact time between cells and seed. Adhesion capacities decreased for every mutant after both short and long times of contact, except for 4834XADA2. For this particular mutant, the adhesion was significantly $(P<0.05)$ less than for the wild type only after the longer time of contact. Adhesion to bean seed of every mutant was lower after $2 \mathrm{~h}$ than after $25 \mathrm{~min}$ of contact whereas adhesion to bean seed of the wild type did not vary in time. Although the role of XadA2 appeared only after the longer time of contact between seed and cells, adhesion measures of a biotic surface suggest that all five adhesins were required for the adhesion on seed.

\section{Mutation in pilA decreased aggressiveness}

\section{of $X$. fuscans subsp. fuscans on bean.}

When inoculated onto bean leaves, every mutant (4834PILA, 4834FHAB, 4834XADA1, 4834XADA2, and 4834YAPH) was able to cause typical water-soaked spots. However, 4834PILA mutant was significantly less aggressive than the wild-type strain as revealed by inoculation at a low concentration $\left(1 \times 10^{6}\right.$ CFU/ml) (Fig. 4). Conversely, the pathogenicity of 4834YAPH was significantly $(P<0.05)$ higher than that of the wild type when inoculated at $1 \times 10^{7} \mathrm{CFU} / \mathrm{ml}$. No significant differences were observed for other mutants compared with the wild type.

\section{Mutation in yapH of $X$. fuscans subsp. fuscans}

partially altered its capacity to colonize bean phyllosphere.

To quantify all bacterial population sizes colonizing the phyllosphere, a rough stomaching of leaves was used. To quantify endophytic population sizes and populations aggregated in biofilms and adherent to leaf surfaces, leaves were disinfected with chloroform vapors before stomaching (Pruvost et al. 2008). Verifications of the efficacy of the chloroform vapor disinfection method included observations that i) 90 to $99 \%$ of solitary cells deposited on bean leaf surfaces were killed following a chloroform treatment right after leaves had dried (Fig. 5) and ii) all cells that were infiltrated into intercellular spaces of the leaf mesophyll were not (data not shown).

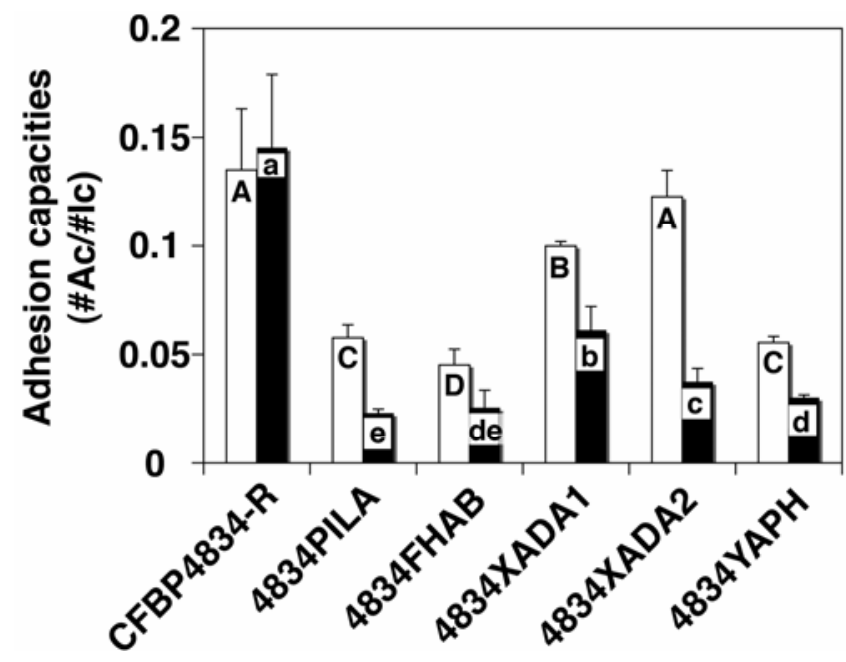

Fig. 3. Quantification of adhesion of Xanthomonas fuscans subsp. fuscans CFB4834-R and 4834PILA, 4834FHAB, 4834XADA1, 4834XADA2, and 4834YAPH mutants to bean seed. Bars represent the ratio of the number of attached cells on seed after 25 min (white) or $2 \mathrm{~h}$ (black) of incubation in inoculum suspensions (\#Ac) versus the total number of inoculated cells (\#Ic). Error bars represent the standard error of the mean. Inoculum was calibrated at $1 \times 10^{5} \mathrm{CFU} \mathrm{ml}{ }^{-1}$. For a given time of contact, different letters refer to significantly different values based on a Mann-Whitney test. Three repetitions of the assay were done with similar results.
Capacities to colonize the phyllosphere were similar for strains 4834PILA, 4834FHAB, 4834XADA2, 4834YAPH, and the wild-type CFBP4834-R when determined after stomaching of leaves (Fig. 5A). No differences were observed among the dynamics and population sizes. However, when the leaf surfaces were disinfected with chloroform vapors, bacterial population enumeration showed that the remaining population sizes of 4834YAPH were significantly $(P<0.05)$ lower than those of the wild type 11 days after inoculation (Fig. 5B). No such differences were observed at the previous sampling dates and for other strains. Similar results were observed for the independent repetitions of the experiment. These results suggest that 4834YAPH was not able to adhere to leaf surfaces and form biofilms.

We confirmed in vitro that wild-type planktonic cells were significantly $(P<0.05)$ more sensitive to chloroform vapors than cells in biofilms. Less than $2 \%$ of the planktonic cells survived to chloroform vapors whereas approximately $33 \%$ of the aggregated cells survived. Mean (standard deviation) control biofilm cell densities were $3.3 \times 10^{4}( \pm 1.13) \mathrm{CFU} / \mathrm{ml}$ whereas mean (standard deviation) chloroform-treated biofilm densities were $1.1 \times 10^{4}( \pm 1.54) \mathrm{CFU} / \mathrm{ml}$. Respective values for planktonic cells were $8.9 \times 10^{6}( \pm 1.66) \mathrm{CFU} / \mathrm{ml}$ and $1.5 \times 10^{6}( \pm 2.52)$ $\mathrm{CFU} / \mathrm{ml}$. Hence, aggregation in biofilms protected cells from chloroform vapors. Because $y a p H$ was required for in vitro biofilm formation, the in planta susceptibility of 4834YAPH populations to disinfection with chloroform vapors strongly suggests that 4834YAPH did not form biofilms in the phyllosphere compared with the wild type (Jacques et al. 2005).

\section{Mutation in pilA and $f h a B$ altered transmission of $X$. fuscans subsp. fuscans to seed.}

According to the method developed by Darsonval and associates (2008) to monitor bacterial transmission to bean seed, plants at the flower-bud stage were spray inoculated with suspensions of the wild-type or mutated strains. With this inoculation procedure, all aerial organs of plants (mainly leaves and buds) were contaminated on their surfaces; later bacteria could

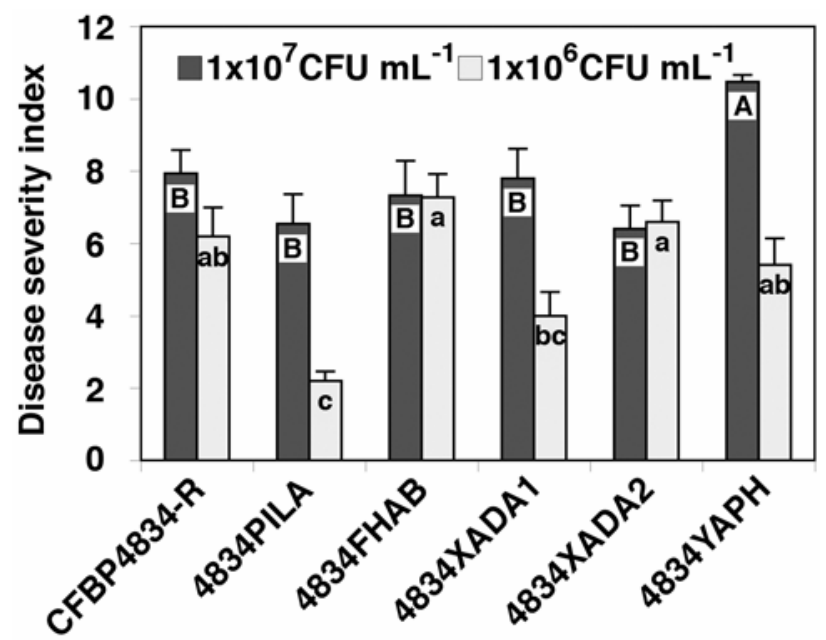

Fig. 4. Severity on bean of wild-type CFBP4834-R and mutants 4834PILA, 4834FHAB, 4834XADA1, 4834XADA2, and 4834YAPH after bathing the first trifoliate leaf in inocula at $1 \times 10^{5}$ and $1 \times 10^{6} \mathrm{CFU} / \mathrm{ml}$. Disease symptoms were scored 11 days after inoculation by quantification of symptoms on the three leaflets of each inoculated leave according to the following scale: no symptoms $=1,1$ to 20 spots $=3,21$ to 40 spots $=6$, $>41$ spots $=9$, and leaf death $=11$. Mean disease severity indexes and standard error of the mean were calculated from the values of five plants per strain. For each inoculum concentration, different letters refer to significantly different values based on a Mann-Whitney test. Three repetitions of the assay were done with similar results. 
ingress in tissues. Using this inoculation procedure, contamination of seed could result from a vascular colonization following bacterial penetration by hydathodes and from a floral contamination following bud and flower colonization. We observed that the 4834PILA mutant was the most altered in its ability to transmit to bean seed, with the lowest transmission rate $(P<0.05)$ (Table 2$)$. The transmission rate of $4834 \mathrm{FHAB}$ mutant was affected compared with the wild type, although not significantly $(P>0.05)$. Transmission rates of 4834XADA1, 4834XADA2, and 4834YAPH mutants were similar to or even slightly higher than that of the wild-type strain. Bacterial population sizes on seed were not significantly different among strains. Thus, PilA was clearly involved in the bacterial transmission to bean seed. The contributions of the other adhesins seemed less obvious. For a better understanding of their respective contribution, it was necessary to differentiate the different contamination pathways and the role of each adhesin in the floral and vascular pathways.

\section{Mutation in pilA, fhaB, and $x a d A 2$ limited} vascular transmission of $X$. fuscans subsp. fuscans

to seed but not its transmission through the floral pathway.

To monitor bacterial transmission to seed through the vascular pathway, bacteria were sprayed on leaves while floral struc-
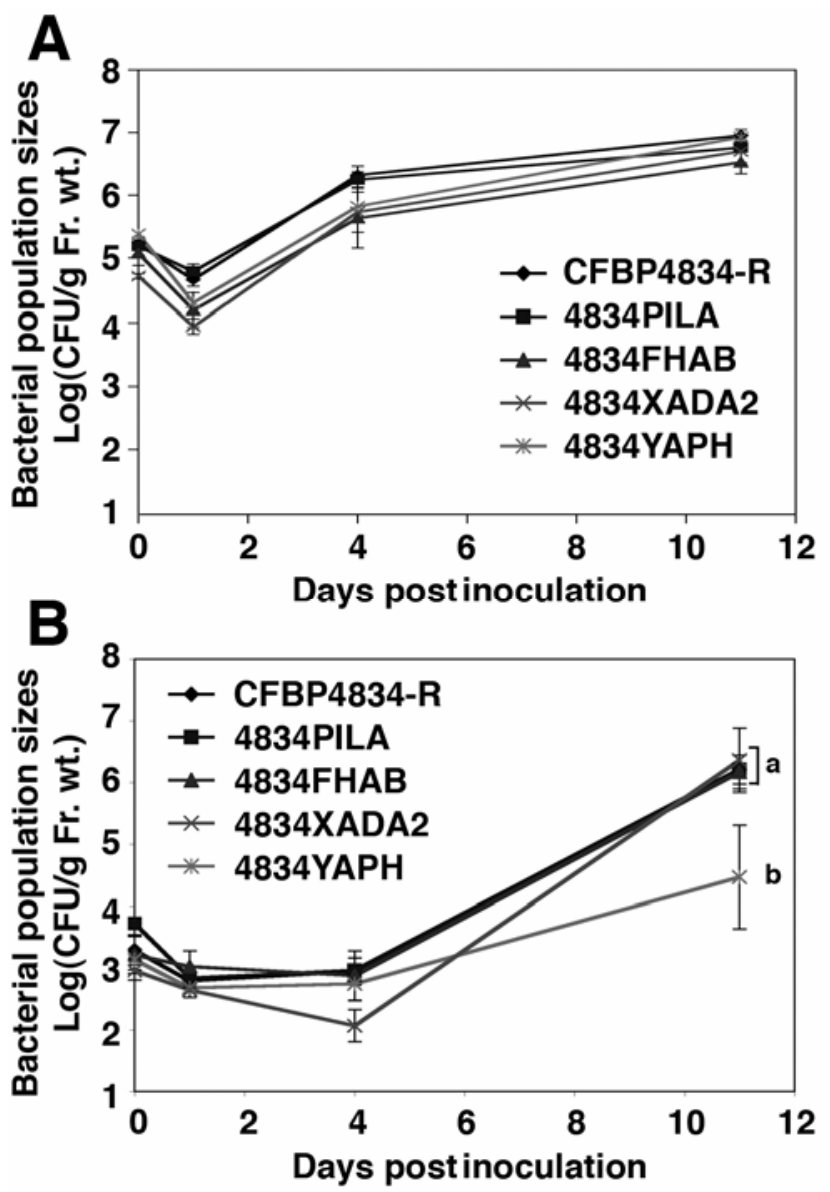

Fig. 5. Colonization of the bean phyllosphere by Xanthomonas fuscans subsp. fuscans wild-type CFBP4834-R and selected mutants 4834PILA, 4834FHAB, 4834XADA2, and 4834YAPH. Leaves were spray inoculated $\left(1 \times 10^{6} \mathrm{CFU} / \mathrm{ml}\right)$. Five leaves were analyzed by stomaching on the day of inoculation, after $3 \mathrm{~h}$ of drying, and 1,4 , and 11 days later. A, Mean bacterial population sizes. B, Mean bacterial population sizes determined after disinfection of the leaf surface with chloroform vapor on each sampling date. Error bars represent the standard error of the mean. Mean population sizes followed by different letters are significantly $(P<0.05)$ different on the basis of the Mann-Whitney test. tures of the plants were protected from any aerial contamination by cellophane bags. With this method, only bacteria that are endophytes or that colonize the vascular system can move from the leaf surfaces to seed (Darsonval et al. 2008). Only the wild type (CFBP4834-R) and 4834YAPH were able to transmit to seed with high frequencies through the vascular pathway (Table 3). Frequencies of transmission to seed were low for 4834PILA, 4834FHAB, and 4834XADA2. Mean bacterial population sizes on seed were low (Table 3 ). To monitor bacterial transmission to seed through the floral pathway, inoculum was directly deposited into flower buds. None of the selected mutants in the nonfimbrial adhesins (4834FHAB, 4834XADA2, and 4834YAPH) was impaired in its ability to infect seed through the floral pathway because transmission rates and associated population sizes were high and similar to those of the wild type (Table 3). When originating from the vascular pathway, mean bacterial population sizes on seed were lower than populations on seed contaminated through the floral structures (Table 3). Altogether, these results suggest that PilA, $\mathrm{XadA}$, and FhaB were required for a vascular transmission to bean seed but not through the floral pathway; YapH was not involved in bacterial transmission to seed either through the floral or the vascular pathways.

\section{DISCUSSION}

To gain insight into the dynamics of $X$. fuscans subsp. fuscans-host interactions during colonization processes, we ana-

Table 2. Transmission rates of Xanthomonas fuscans subsp. fuscans strain CFBP4834-R and of mutants 4834PILA, 4834FHAB, 4834XADA1, 4834XADA2, and 4834YAPH to bean seed after spray inoculation $(1 \times$ $10^{5} \mathrm{CFU} / \mathrm{ml}$ ) of plants at the flower bud stage $\mathrm{a}^{\mathrm{a}}$

\begin{tabular}{llc}
\hline Strain & $\begin{array}{c}\text { Transmission } \\
\text { rate }^{\mathbf{b}}\end{array}$ & $\begin{array}{c}\text { Bacterial population size } \\
\text { (log CFU/g fw) (SEM) }\end{array}$ \\
\hline CFBP4834-R & 0.68 & $3.77(0.45)$ \\
4834PILA & $0.40^{*}$ & $3.06(0.48)$ \\
4834FHAB & 0.58 & $4.43(0.51)$ \\
4834XADA1 & 0.70 & $3.77(0.40)$ \\
4834XADA2 & 0.72 & $4.29(0.39)$ \\
4834YAPH & 0.75 & $3.77(0.42)$ \\
\hline
\end{tabular}

${ }^{a}$ Rates of plants producing contaminated seed out of 50 inoculated plants for each strain are indicated followed by the mean bacterial population sizes per gram of seed (and standard error of the mean [SEM]) for plants with contaminated seed. $\mathrm{fw}=$ fresh weight

${ }^{\mathrm{b}}$ An asterisk $(*)$ indicates significant $(P<0.05)$ different values from the wild-type CFBP4834-R, according to a $\chi^{2}$ test.

Table 3. Transmission rates to bean seed and associated mean population sizes of the wild-type CFBP4834-R and 4834PILA, 4834FHAB, 4834XADA2, and 4834YAPH strains through the floral and the vascular pathways $^{\mathrm{a}}$

\begin{tabular}{llllll}
\hline & \multicolumn{2}{c}{ Floral pathway } & & \multicolumn{2}{c}{ Vascular pathway } \\
\cline { 2 - 3 } \cline { 6 - 6 } Strains & Rate & Size $($ SEM) & & Rate & Size $($ SEM) \\
\hline CFBP4834-R & 0.8 & $6.06(0.75)$ & & 0.6 & $1.80(0.40)$ \\
4834PILA & 0.9 & $4.81(0.83)$ & & 0.1 & $1.34(\mathrm{nd})$ \\
4834FHAB & 0.9 & $6.79(0.41)$ & & 0.2 & $0.96(0.18)$ \\
4834XADA2 & 1 & $7.06(0.21)$ & & 0.1 & $0.78(\mathrm{nd})$ \\
4834YAPH & 0.9 & $6.87(0.67)$ & & 0.5 & $3.91(1.15)$ \\
\hline
\end{tabular}

${ }^{\text {a }}$ Transmission to seed through the floral pathway was determined following inoculations of flower buds by depositing inoculum $\left(1 \times 10^{6} \mathrm{CFU} / \mathrm{ml}\right)$ in flower buds. Transmission to seed through the vascular pathway was obtained by spraying the phyllosphere of plants with a $1 \times 10^{5} \mathrm{CFU} / \mathrm{ml}$ suspension. Six weeks after inoculation, bacterial population sizes were quantified in seed from 10 plants per strain and per treatment. Rate $=$ transmission rate, Size $(\mathrm{SEM})=$ bacterial population sizes $(\log \mathrm{CFU} / \mathrm{g}$ fresh weight) (standard error of the mean $[$ SEM]), and nd $=$ not determined. 
lyzed the role of bacterial surface structures in survival and multiplication on leaves, transmission, and adhesion to seed. In planta characterization of mutant behavior followed the determination of the role of adhesins in bacterial adhesion in vitro and formation of biofilms. The five different genes coding adhesin structures identified in $X$. fuscans subsp. fuscans contributed at various levels in host colonization. Although pilA was involved in bacterial adhesion to seed and transmission to seed, yapH was essential for adhesion to seed, leaves, and abiotic surfaces but not for in planta transmission to seed. The contributions of $x a d A 1, x a d A 2$, and $f h a B$ were partial in seed adhesion and transmission to seed. The only significant impact of the mutations in bacterial phyllospheric colonization was the lesser resistance of 4834YAPH to chloroform vapors manifesting its alteration in biofilm formation.

Dispersion of a pathogen is a major determinant of fitness (Fenton et al. 2002; McCallum et al. 2001). Transmission by seed is one of the most efficient means of dispersion for the majority of the plant-pathogenic bacteria (Gitaitis and Walcott 2007). However, determinants of this biological process are still poorly understood. Recently, we demonstrated that the T3SS of X. fusans subsp. fuscans and its master regulators HrpG and HrpX are major determinants of bacterial transmission to seed (Darsonval et al. 2008). Mainly, T3SS regulatory and structural genes are required for bacterial transmission to seed through the vascular pathway. Here, we showed that PilA fimbrial protein and, to a lesser extent, XadA1 and FhaB were also involved in transmission of $X$. fuscans subsp. fuscans to bean seed by the vascular pathway. However, the intimate mechanisms depending on adhesins and resulting in bacterial colonization of xylem vessels and, ultimately, transmission to seed remain to be discovered. Darsonval and colleagues (2008) showed that T3SS is also implicated in bacterial transmission through the floral pathway. In contrast, here we showed that none of the adhesins seemed to be required for transmission to seed through the floral pathway. This is consistent with the fact that flowers are considered excellent microbial habitats, being well supplied with nutrients (Ngugi and Scherm 2006) and offering protected habitats against abiotic stresses. Furthermore, flowers provide short-lived but nonhostile environments to microbes (Stockwell 2005), and long-term advantages conferred by adhesion and aggregation in biofilms are not necessary to survive in this ephemeral habitat and have no time to take place.

Although both fimbrial and nonfimbrial adhesins appeared to contribute to initial attachment to abiotic surfaces such as $\mathrm{PP}, \mathrm{YapH}$ played an essential role in this step. Mutation in yapH totally impaired $X$. fuscans subsp. fuscans for in vitro adhesion to PP. In contrast, mutation in pilA, fhaB, and $x a d A 2$ partially modified adhesion capacities of $X$. fuscans subsp. fuscans to this surface. Our results confirmed a recent study suggesting that nonfimbrial $\mathrm{HxfB}$ proteins (filamentous hemagglutinins) of Xylella fastidiosa are involved in adhesion on glass, another abiotic surface (Feil et al. 2007). As observed for X. fastidiosa (Feil et al. 2007), we did not see evidence of cell-to-cell aggregates (pellicles) formed within broth cultures for the Xanthomonas fuscans subsp. fuscans wild type but, instead, biofilm formation was recorded (i.e., aggregation of cells to each other after some cells had attached to a surface). Although adhesion to PP surface was decreased for mutants in fimbrial (PilA) and nonfimbrial (FhaB and XadA2) adhesins, all mutants in adhesins except in nonfimbrial YapH were still able to initiate attachment to abiotic surfaces, the first step in biofilm formation. Hence, we can speculate, as Feil and associates (2007) did that the process of biofilm formation involves the sequential contribution of primarily and essentially a nonfimbrial adhesin (YapH for $X$. fuscans subsp. fuscans) to initial attachment of cells to the abiotic surface, whereas secondarily cells can be added to the primary colonists by a process involving pili. We cannot eliminate the possibility of other adhesins involved in this phenomenon. Sequencing of the X. fuscans subsp. fuscans genome may reveal the existence of other genes coding adhesins that we could not identify with our strategy. Results found for the adhesion to biotic surfaces are also consistent with this model, in which adhesins contribute sequentially in adhesion to surface and, later, cell-to-cell aggregation. FhaB and $\mathrm{YapH}$ are necessary for initial attachment as determined after 25 min of contact time between seed and bacterial suspensions. Contribution of other adhesins and especially the fimbrial one, PilA, is dominant later.

Several adhesins of $X$. fuscans subsp. fuscans seem to be involved in its pathogenicity on bean. Indeed, we observed that aggressiveness of $X$. fuscans subsp. fuscans on bean was strongly attenuated by the disruption of pilA but increased by the disruption of yapH and remained unmodified for other genes coding adhesins. As previously shown for fimbrial adhesins of Ralstonia solanacearum, X. citri subsp. citri, and $X$. campestris pv. hyacinthi (Kang et al. 2002; Ojanen-Reuhs et al. 1997; van Doorn et al. 2001), the type IV pili of X. fuscans subsp. fuscans contributed to aggressiveness on its host, as revealed by the mutation of pilA. In contrast, mutation of $y a p H$ increased aggressiveness of $X$. fuscans subsp. fuscans. It has previously been shown that yapH could act as an antivirulence gene (Foreman-Wykert and Miller 2003). Mutations in such a locus result in a hypervirulent phenotype, as measured by a lower lethal dose and a colonization advantage (ForemanWykert and Miller 2003). We were not able to show any substantial involvement of other adhesins in pathogenicity of $X$. fuscans subsp. fuscans on bean even with different inoculum concentration and inoculum procedures (data not shown). However, results obtained separately for mutants of Xyllella fastidiosa in HxfA (Guilhabert and Kirkpatrick 2005) and HxfB (Feil et al. 2007) adhesins were not consistent: a mutant in the $h x f A$ produced more severe symptoms and earlier grapevine death, whereas a mutant in $h x f B$ exhibited lower incidence of disease. The nonfimbrial adhesin XadA is required for optimum virulence in Xanthomonas oryzae pv. oryzae (Ray et al. 2002). For E. chrysanthemi, Rojas and associates (2002) reported that each mutant in filamentous hemagglutinin $\mathrm{Hec} A$ has limited leaf surface attachment and aggregate formation, failed to express macerating enzymes, and was avirulent. Furthermore, the hecA::Tn7 hemagglutinin mutant was reduced in virulence on Nicotiana clevelandii seedlings after inoculation without wounding (Rojas et al. 2002).

YapH is the only adhesin of $X$. fuscans subsp. fuscans CFBP4834-R required for a complete phyllosphere colonization process, as demonstrated by quantification of population sizes adherent to leaves following surface disinfection with chloroform vapors. This behavior of the strain 4834YAPH mutated in yapH could be associated with its total incapacity to adhere to biotic and abiotic surfaces and to form biofilms. This disadvantage for surface colonization under highly stressful conditions could, in turn, be an advantage because it could allow extensive colonization of vessels, leading to an extensive development of symptoms. This hypothesis can be supported by data obtained with the pathosystem $X$. fastidiosa and Vitis vinifera (Guilhabert and Kirkpatrick 2005). In this case, ability to form biofilms in planta leads to the congestion of some rare vessels whereas, for mutants in $r p f F$, a high proportion $(>80 \%)$ of vessels were colonized by large population sizes of planktonic cells able to disperse in vascular system and, consequently, to provoke symptoms (Newman et al. 2004). This is coherent with the efficient transmission of 4834YAPH of $X$. fuscans subsp. fuscans mutated in yapH to bean seed through the vas- 
cular pathway. This last observation allows us to confirm that $y a p H$ is required for leaf adhesion and, more generally, for biofilm formation on leaf surfaces but not for its ingress in host tissues.

Pathogenic bacteria have evolved an incredibly large and diverse array of adhesion proteins to exploit a variety of host cell-surface components (Pizarro-Cerda and Cossart 2006). The results reported in this study present the individual and complementary contribution of five adhesins of $X$. fuscans subsp. fuscans during colonization of the phyllosphere and transmission to the seed. These results are coherent with the idea that xanthomonads host a large repertoire of bacterial surface structures necessary to exploit the various environments they have to face in their lives. Indeed, we showed that each of the five identified adhesins in X. fuscans subsp. fuscans was involved in at least one of the various steps of phyllosphere and anthosphere colonization during colonization of its host.

\section{MATERIALS AND METHODS}

\section{Bacterial strains, plasmids, and grown conditions.}

The bacterial strains and plasmids used in this study are described in Table 4. Xanthomonad strains were grown at $28^{\circ} \mathrm{C}$ in $10 \%$ TSA medium (tryptone at $1.7 \mathrm{~g} /$ liter, soybean peptone at $0.3 \mathrm{~g} /$ liter, glucose at $0.25 \mathrm{~g} /$ liter, $\mathrm{NaCl}$ at $0.5 \mathrm{~g} /$ liter, $\mathrm{K}_{2} \mathrm{HPO}_{4}$ at $0.5 \mathrm{~g} / \mathrm{liter}$, and agar at $\left.15 \mathrm{~g} / \mathrm{liter}\right), 10 \% \mathrm{TSB}(10 \%$ TSA without agar), or in MME minimal medium $\left(\mathrm{K}_{2} \mathrm{HPO}_{4}\right.$ at $10.5 \mathrm{~g} /$ liter, $\mathrm{KH}_{2} \mathrm{PO}_{4}$ at $5.4 \mathrm{~g} /$ liter, $\left(\mathrm{NH}_{4}\right)_{2} \mathrm{SO}_{4}$ supplemented

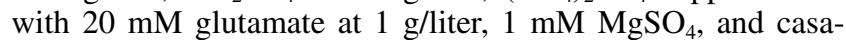
mino acids at $0.15 \mathrm{~g} /$ liter) (Arlat et al. 1991). Escherichia coli cells were cultivated at $37^{\circ} \mathrm{C}$ in Luria-Bertani medium (tryptone at $10 \mathrm{~g} / \mathrm{liter}$, yeast extract at $5 \mathrm{~g} / \mathrm{liter}, \mathrm{NaCl}$ at $5 \mathrm{~g} / \mathrm{liter}$, and agar at $15 \mathrm{~g} / \mathrm{liter}$ ). SOB + glycerol (SOBG) medium (Yap et al. 2005) was used to induce aggregation in glass tubes. Media were supplemented with appropriate antibiotics. Antibiotics were used at the following final concentrations: rifamycin at $50 \mathrm{mg} / \mathrm{liter}$, kanamycin at $25 \mathrm{mg} / \mathrm{liter}$, rifampicin at 50 $\mathrm{mg} / \mathrm{liter}$, chloramphenicol at $12.5 \mathrm{mg} / \mathrm{liter}$, and tetracycline at $10 \mathrm{mg} /$ liter. For in planta studies, media were supplemented with cycloheximide at $50 \mathrm{mg} /$ liter and propiconazole at 10 $\mathrm{mg} / \mathrm{liter}$ to inhibit fungal growth. To prepare inocula, strains were grown for $48 \mathrm{~h}$ in $10 \%$ TSA supplemented with appropriate antibiotics. Bacterial streak cultures were suspended in sterile water by sterile swab to $1 \times 10^{8} \mathrm{CFU} / \mathrm{ml}$. Suspensions were adjusted to the desired final concentrations with sterile distilled water.

\section{Plant material.}

In planta experiments were conducted with a variety of common bean (P. vulgaris cv. Flavert) susceptible to common bacterial blight. Seed were provided by Vilmorin and were considered to be free of $X$. fuscans subsp. fuscans following the analysis of approximately 100,000 seed per lot with standard tests (International Seed Testing Association 2007). When necessary, seed were sown in 10-by-10-by-18-cm pots (1 seed per pot) containing soil substrate (Neuhaus humin substrat S NF 11-44-551; Proveg, La Rochelle, France). Bean plants were grown in a growth chamber until the first trifoliate leaf was fully expanded (Michael 1994) or until the flower bud stage (5 weeks old) (Michael 1994), depending on the experiments. Bean plants were grown in growth chambers under $16 \mathrm{~h}$ of light at $25^{\circ} \mathrm{C}\left(28^{\circ} \mathrm{C}\right.$ for pathogenicity tests $)$ and $8 \mathrm{~h}$ of darkness at $20^{\circ} \mathrm{C}\left(22^{\circ} \mathrm{C}\right.$ for pathogenicity tests) and under high $(95 \%)$ relative humidity $(\mathrm{RH})$. Before inoculations, plants were incubated under $16 \mathrm{~h}$ of light at $25^{\circ} \mathrm{C}$ and $8 \mathrm{~h}$ of darkness at $20^{\circ} \mathrm{C}$ and $95 \% \mathrm{RH}$. For experiments on phyllosphere colonization and transmission to seed, RH was decreased to $50 \%$ from 2 days after inoculation. Plants were watered three times per week and supplemented with N-P-K (18:14:18) at 0.3 $\mathrm{g} /$ liter once a week. Plant inoculations were carried out under quarantine at UMR PaVé, Centre INRA, Beaucouzé, France. To avoid cross-contaminations, plants receiving a similar treatment were grouped in a growth chamber and were separated by polypropylene curtains from other treatments. Every experiment with plants was repeated at least three times.

\section{Molecular biology techniques.}

Chromosomal DNA was extracted with the Nucleospin tissue kit (Macherey-Nagel, Hoerdt, France). Plasmid preps were performed with the Wizard Plus Minipreps DNA purification systems (Promega, Charbonniéres, France). Restriction enzymes, DNA ligase, and GoTaq DNA Polymerase (Promega) were used according to the manufacturer's recommendations. PCR assays were performed in 20- $\mu$ l volumes containing 200 $\mu \mathrm{M}$ dNTP, $1.5 \mathrm{mM} \mathrm{MgCl}, 0.5 \mu \mathrm{M}$ each primer (Table 2), 0.4 $\mathrm{U} / \mu \mathrm{l}$ of GoTaq polymerase, and $4 \mu \mathrm{l}$ of a boiled bacterial suspension $\left(1 \times 10^{7} \mathrm{CFU} / \mathrm{ml}\right)$. PCR conditions were $5 \mathrm{~min}$ at $94^{\circ} \mathrm{C}$; followed by 35 cycles of $30 \mathrm{~s}$ at $94^{\circ} \mathrm{C}, 30 \mathrm{~s}$ at $55^{\circ} \mathrm{C}$, and $1 \mathrm{~min}$ at $72^{\circ} \mathrm{C}$; and ended with $7 \mathrm{~min}$ at $72^{\circ} \mathrm{C}$. Southern hybridizations were performed using gene- and vector-specific PCR fragments as probes. Probes were labeled using the PCR digoxigenin (DIG) labeling mix (Roche Applied Science, Meylan, France). Genomic DNA was digested by BamHI and transferred to nylon membrane Hybond $\mathrm{N}^{+}$(Amersham,

Table 4. Strains and plasmids used in this study

\begin{tabular}{|c|c|c|}
\hline Strain or plasmid & Relevant genotype or characteristics ${ }^{\mathbf{a}}$ & Source or reference \\
\hline \multicolumn{3}{|l|}{ Plasmids } \\
\hline pVO155 & Derivative plasmid of pUC19 containing the promoterless gus (uidA) gene; $\mathrm{Km}^{\mathrm{r}}, \mathrm{Amp}^{\mathrm{r}}, \mathrm{Bleo}^{\mathrm{r}}$ & Oke and Long 1999 \\
\hline pRK600 & $\mathrm{Cm}^{\mathrm{r}}$, traRK2, oriColE1 & Finan et al. 1986 \\
\hline pCM184 & Broad-host-range allelic exchange vector & Marx and Lidstrom 2002 \\
\hline pCM157 & Broad-host-range cre expression vector & Marx and Lidstrom 2002 \\
\hline \multicolumn{3}{|c|}{ (1) } \\
\hline CFBP4834-R & Xanthomonas fuscans subsp. fuscans CFBP4834-R wild-type; Rif $^{r}$ & Jacques et al. 2005 \\
\hline K12 & Escherichia coli wild-type strain & Devoret and Blanco 1970 \\
\hline DH5 $\alpha$ & $\begin{array}{l}\text { E. coli } \mathrm{F}, \Phi 980 \mathrm{~d} l a c Z: \mathrm{M} 15, \text { recA1, endA1, gyrA96, thi-1, hsdR17( }\left(\mathrm{rK}^{-}, \mathrm{mK}^{+}\right) \text {, supE44, relA1, } \\
\text { deoR,:(lacZYA-argF)U169 }\end{array}$ & Hanahan 1983 \\
\hline \multicolumn{3}{|c|}{ 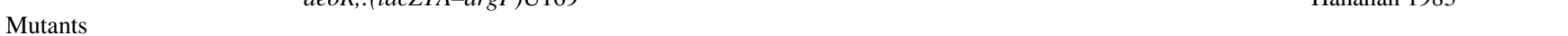 } \\
\hline 4834FHAB & CFBP4834-R fhaB(592)::pVO155; Rif $^{\mathrm{r}}, \mathrm{Km}^{\mathrm{r}}$ & This study \\
\hline 4834XADA1 & CFBP4834-R xadA1(618)::pVO155; iff $^{\mathrm{r}}, \mathrm{Km}^{\mathrm{r}}$ & This study \\
\hline 4834XADA2 & CFBP4834-R xadA2(538)::pVO155; Rif $^{\mathrm{r}}, \mathrm{Km}^{\mathrm{r}}$ & This study \\
\hline 4834YAPH & CFBP4834-R yapH(356)::pVO155; Rif $^{\mathrm{r}}, \mathrm{Km}^{\mathrm{r}}$ & This study \\
\hline 4834PILA & CFBP4834-R $\triangle$ pilA & This study \\
\hline
\end{tabular}

${ }^{\mathrm{a}} \mathrm{Km}^{\mathrm{r}}, \mathrm{Amp}^{\mathrm{r}}, \mathrm{Bleo}^{\mathrm{r}}, \mathrm{Cm}^{\mathrm{r}}$, and $\mathrm{Rif}^{\mathrm{r}}=$ resistant to kanamycin, ampicillin, bleomycin, chloramphenicol, and rifampicin, respectively. In the mutants section, numbers in parentheses indicate the position from start codon of pVO155 insertion in the target gene in X. citri subsp. citri 306. 
Pantin, France) according to the supplier's instructions. Blots were hybridized for $16 \mathrm{~h}$ at $42^{\circ} \mathrm{C}$ in $50 \%$ formamide, $5 \times \mathrm{SSC}$ ( $1 \times \mathrm{SSC}$ is $0.15 \mathrm{M} \mathrm{NaCl}$ plus $0.015 \mathrm{M}$ sodium citrate), $20 \%$ sodium dodecyl sulfate (SDS), $2 \%$ blocking reagent, and $0.1 \%$ $\mathrm{N}$-lauryl-sarcosine, followed by washes in $2 \times \mathrm{SSC}, 0.1 \% \mathrm{SDS}$, and $0.1 \times \mathrm{SSC}, 0.1 \% \mathrm{SDS}$ at $68^{\circ} \mathrm{C}$. The probes were detected using the Fab fragments of an anti-DIG antibody conjugated with alkaline phosphatase (anti-DIG-AP) and nitro-blue tetrazolium chloride/5-bromo-4-chloro-3'-indolyphosphate p-toluidine salt (NBT/BCIP) solution according to the supplier's instructions (Roche Applied Science).

Total RNA of each strain was isolated by a modification of the method of Piper and associates (1999). A 2-ml late-exponentialphase culture grown in $10 \%$ TSA was centrifuged $30 \mathrm{~s}$ at 14,000 $\times g$. The pellet was resuspended in of $600 \mu \mathrm{l}$ of hot $\left(65^{\circ} \mathrm{C}\right)$ Trizol (Invitrogen, Cergy Pontoise, France) and the mixture was shaken at $65^{\circ} \mathrm{C}$ for $5 \mathrm{~min}$. After $5 \mathrm{~min}$ at room temperature, the cell debris was removed by centrifugation $(2,500 \times g, 5 \mathrm{~min}$ at $15^{\circ} \mathrm{C}$ ) and the supernatant was transferred to a fresh tube. Chloroform $(120 \mu \mathrm{l})$ was added to $600 \mu \mathrm{l}$ of the supernatant and the mixture was vortexed vigorously $30 \mathrm{~s}$. After $2 \mathrm{~min}$ at room temperature, the phases were separated by centrifugation at $12,000 \times g$ for $15 \mathrm{~min}$ at $4^{\circ} \mathrm{C}$ and the upper phase $(300 \mu \mathrm{l})$ was removed to a fresh tube. Isopropyl alcohol $(250 \mu \mathrm{l})$ was added and the mixture was incubated at room temperature for $10 \mathrm{~min}$. The precipitated RNA was collected by centrifugation at 12,000 $\times g$ for $20 \mathrm{~min}$ at $4^{\circ} \mathrm{C}$. The supernatant was removed and the pellet was washed with $500 \mu \mathrm{l}$ of $75 \%$ ethanol. A new pellet of RNA was collected by centrifugation at 7,500 $\times g$ for $5 \mathrm{~min}$ at $4^{\circ} \mathrm{C}$ and was air dried to near completion. The RNA was dissolved in $89 \mu \mathrm{l}$ of sterile double-distilled $\mathrm{H}_{2} \mathrm{O}$, and the preparation was treated with $1 \mu \mathrm{l}$ of DNase (Ambion Applied Biosys-

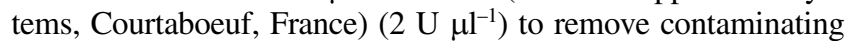
DNA during $1 \mathrm{~h}$ at $37^{\circ} \mathrm{C}$. The preparation was heated $10 \mathrm{~min}$ at $75^{\circ} \mathrm{C}$ to inactivate the DNAse and RNA was ethanol precipitated and dissolved in $50 \mu \mathrm{l}$ of double-distilled $\mathrm{H}_{2} \mathrm{O}$. Total RNA (5 $\mu \mathrm{g})$ was reverse transcribed into cDNA in a $35-\mu \mathrm{l}$ volume using a $15-\mu \mathrm{l}$ mix of $11-$ mer primers at $10 \mu \mathrm{M}$ each (Fislage et al. 1997), $8 \mu \mathrm{l}$ of dNTP at $2.5 \mathrm{mM}, 0.8 \mu \mathrm{l}$ of RNasin $(40 \mathrm{U} / \mu \mathrm{l})$ (Promega, France), and $0.2 \mu \mathrm{l}$ of reverse transcriptase $(200$ $\mathrm{U} / \mu \mathrm{l}$ ) (Promega, France). Reaction mixture was incubated 10 min at $65^{\circ} \mathrm{C}, 5 \mathrm{~min}$ at $4^{\circ} \mathrm{C}$, and $1 \mathrm{~h}$ at $42^{\circ} \mathrm{C}$. The RNA-cDNA mix was ethanol precipitated, dissolved in double-distilled $\mathrm{H}_{2} \mathrm{O}$, and used for PCR reactions.

\section{Mutagenesis techniques to construct}

$X$. fuscans subsp. fuscans CFBP4834-R mutants in adhesins.

Specific primers (Table 1) for each target gene were designed based on consensus sequences obtained by comparison of sequences from $X$. citri subsp. citri 306 (da Silva et al. 2002), $X$. axonopodis pv. vesicatoria 85-10 (Thieme et al. 2005), $X$. oryzae pv. oryzae strain. KACC10331 (Lee et al. 2005), and X. campestris pv. campestris ATCC33913 (Qian et al. 2005) available in the GenBank database. Multiple alignments were performed using ClustalW2 at the EMBL-EBI.

Identification of homologues of these genes was checked by PCR in the CFBP4834-R. The CFBP4834-R deletion mutant lacking pilA was generated using the allelic exchange vector pCM184 (Marx and Lidstrom 2002). Two DNA fragments (543 and $604 \mathrm{bp}$ ) were PCR amplified in pilA of $X$. fuscans subsp. fuscans CFBP4834-R using primers described in Table 1. They were cloned in pCM184 in the ApaI-SacI and EcoRI-NotI cloning sites, respectively. These cloning sites flanked the loxP sites boarding a kanamycin cassette. A marker-exchange kanamycinresistant mutant of CFBP4834-R was then generated by triparental mating using the mobilizing E. coli K12 (pRK600) (Finan et al. 1986). Unmarked deletion 4834PILA mutant was gener- ated using the cre-expressing plasmid pCM157. This plasmid provides expression of a Cre recombinase that catalyses in vivo excision of DNA regions flanked by co-directional loxP recognition sites (Marx and Lidstrom 2002). The pilA region of the mutant was sequenced to validate the deletion. Absence of functional domains in the remaining pilA fragment of the mutated strain was analyzed with InterProScan. A stop codon was inserted after the 273rd nucleotide position.

For specific inactivation of other genes in CFBP4834-R, a plasmid-integration mutagenesis strategy was used as previously described (Oke and Long 1999). A fragment of each target gene was amplified using specific oligonucleotidic primers (Table 1). The PCR fragment was ligated into the suicide vector pVO155 (Oke and Long 1999) and this construction was introduced into $E$. coli DH5 $\alpha$. PCR fragments cloned into the pVO155 were sequenced to verify their identity with BlastN (Altschul et al. 1997). Plasmid was transferred into the strain CFBP4834-R by triparental mating (Arlat et al. 1992; Glazebrook and Walker 1991) using the mobilizing $E$. coli K12 (pRK600) (Finan et al. 1986). Disruption of each target gene was verified by i) PCR using one primer in the plasmid (proR or proF) and a second primer in the genome outside the recombinant region (Table 2), ii) Southern blotting using the recombinant fragment as a specific probe and a vector-specific probe (Table 2) to confirm single insertion, and iii) RTPCR to confirm that no mRNA were transcribed from the mutated gene using specifically designed primers (Table 2). Primers (HrpG-F and HrpX-R2) (Darsonval et al. 2008) designed in two contiguous genes with opposite orientations $h r p G$ and $h r p X$ were used to show the absence of contaminant DNA in each sample. Primers (Table 2) designed in orf3 of the pig locus of X. oryzae pv. oryzae BX01 (Goel et al. 2002) were used as positive control for each sample because this gene is transcribed in our conditions.

The stability of the constructions was verified in vitro by testing the kanamycin resistance of the insertion mutants. Liquid cultures at an initial concentration of $1 \times 10^{6} \mathrm{CFU} / \mathrm{ml}$ of each strain were cultured in $10 \%$ TSB without antibiotic selection pressure at $28^{\circ} \mathrm{C}$ under constant agitation (120 rpm); $24 \mathrm{~h}$ later, they were $10 \times$ diluted and grown up again, and this step was repeated for 4 days. Finally, bacterial populations were plated on selective and nonselective media (10\% TSA) and population sizes were compared. Three independent cultures of every strain were analyzed and the experiment was repeated three times. The stability of the mutation was also verified in planta by comparison of the bacterial population sizes on selective and nonselective media the day of inoculation and at the last sampling date. To confirm stability of the construction versus antibiotic resistance acquisition and to check for crosscontamination among treatments, the identity of 10 colonies per plant that developed on the nonselective medium was verified by PCR using specific primers (Table 1).

To assess that mutations had no impact on in vitro growth, growth curves were established for each mutant and the wildtype strain CFBP4834-R by growing strains at an initial concentration of $1 \times 10^{7} \mathrm{CFU} / \mathrm{ml}$ in 100 -well honeycomb microtiter plates (Thermo Electron, Courtaboeuf, France) in 10\% TSB. Plates were incubated at $28^{\circ} \mathrm{C}$ with continuous shaking over a period of $30 \mathrm{~h}$. Growth measurements were monitored automatically every $2 \mathrm{~h}$ by optical density measurements at $600 \mathrm{~nm}$ using the Bioscreen C instrument (Labsystems, Helsinki, Finland). Noninoculated wells were used as aseptic controls. The experiment was repeated three times for each strain.

\section{In vitro and in planta adhesion assays.}

Bacterial adhesion under static conditions was quantified by a $\mathrm{CV}$ incorporation assay with 96 -well polypropylene micro- 
titer plates (Microwell, Nunc, Denmark) using a modification of a previously reported protocol (O'Toole and Kolter 1998). Every well was fulfilled with $200 \mu \mathrm{l}$ of MME minimal medium per well. Three wells per strain, each containing $200 \mu \mathrm{l}$ of MME minimal medium, were inoculated with 1:20 dilutions of an inoculum calibrated at $1 \times 10^{7} \mathrm{CFU} \mathrm{m}^{-1}$ and incubated at $28^{\circ} \mathrm{C}$ for 3 days. Then, supernatants containing planktonic bacteria were transferred into a 96-well plate (Nunclon, Nunc, Denmark) to determine their optical density at $600 \mathrm{~nm}\left(\mathrm{OD}_{600}\right)$ using the $\mu$ Quant platewell reader (Bio-Tek Instruments, Inc., Winooski, VT, U.S.A.) as an indication of bacterial growth. To quantify surface-attached bacteria, the 96-well PP microtiter plates were rinsed twice with distilled water, and surfaceattached cells were stained for $15 \mathrm{~min}$ at room temperature with a $1 \%(\mathrm{wt} / \mathrm{vol}) \mathrm{CV}$ solution at $200 \mu \mathrm{l} /$ well. Then, supernatants were discarded, the wells were washed thoroughly and repeatedly with distilled water, and, finally, the dye incorporated in attached cells was solubilized in $200 \mu$ of $95 \%$ ethanol per well and the $\mathrm{OD}_{600}$ was determined in the microplate reader. These tests were repeated at least three times for every bacterial strain.

Bacterial adhesion to bean seed was tested as previously described (DeFlaun et al. 1994), with some modifications. To evaluate the adhesion ability of the wild-type and mutant strains, series of three independent columns were filled with $12 \mathrm{~g}$ of bean seed and fully saturated with $6 \mathrm{ml}$ of inoculum at $1 \times 10^{5} \mathrm{CFU} / \mathrm{ml}$. The contact time between the culture and the seed was $25 \mathrm{~min}$ and $2 \mathrm{~h}$. After removal of the inoculum, columns were washed twice with $6 \mathrm{ml}$ of distilled water. To quantify bacterial cells adherent to seed, seed of each column were soaked overnight at $4^{\circ} \mathrm{C}$ in $24 \mathrm{ml}$ of sterile distilled water. Every sample was then vigorously shaken, and appropriate dilutions were spiral plated (Spiral Biotech, Bethesda, MD, U.S.A.) on selective medium to enumerate bacterial population sizes. These tests were repeated at least three times for every bacterial strain.

\section{Biofilm and pellicle assay.}

The method developed by Yap and associates (2005) was used and completed with a CV coloration step. Bacterial cultures were suspended in SOBG to approximately $1 \times 10^{7}$ $\mathrm{CFU} / \mathrm{ml}$. Cultures were incubated at $28^{\circ} \mathrm{C}$ in stationary $13-\mathrm{mm}$ glass tubes for 7 days. Pellicle and biofilm formation were evaluated by visual examination of the culture surface and of the size of the ring deposited on the glass. Then, liquid cultures were eliminated from tubes and remaining biofilms adherent to the glass were stained with $5 \mathrm{ml}$ of a $1 \%$ (wt/vol) $\mathrm{CV}$ solution. After $15 \mathrm{~min}$ of incubation, $\mathrm{CV}$ solution was discarded and tubes were gently rinsed by adding $5 \mathrm{ml}$ of sterile water three times. Biofilm formation was observed visually.

\section{Pathogenicity tests.}

Tests were performed by immersing whole trifoliate leaf of bean at the V3 stage (Michael 1994) into bacterial suspensions calibrated at $1 \times 10^{7}$ and $1 \times 10^{6} \mathrm{CFU} / \mathrm{ml}$. This method allowed homogeneous and reproducible inoculations and limited inoculum dispersal in the growth chamber. One leaf per plant and three plants per strain were inoculated. Symptoms were recorded on the 11th day following inoculation. Symptom development on each inoculated leaflet was individually scored using the following scale: $1=$ no symptoms, $3=1$ to 20 spots, $6=21$ to 40 spots, $9=>41$ spots, and $11=$ leaf death.

\section{Sterilization of the leaf surface and dynamics of bacterial population sizes in bean phyllosphere.}

Plants at the first trifoliate stage (Michael 1994) were spray inoculated until runoff with bacterial suspensions at $1 \times 10^{6}$
$\mathrm{CFU} / \mathrm{ml}$. The first trifoliate leaf of five plants per treatment was sampled $3 \mathrm{~h}$ and 1,4 , and 11 days after inoculation. To remove planktonic cells and have access to the adherent and aggregated phyllospheric bacterial populations, a surface sterilization assay was used. One leaflet of each leaf was placed for $3 \mathrm{~min}$ in a saturated chloroform vapor box ( $1 \mathrm{ml}$ of chloroform in a $0.37 \times 10^{-3} \mathrm{~m}^{3}$ closed box) and then its bacterial content was analyzed. The two other leaflets were directly analyzed for their bacterial content. Total bacterial population sizes were quantified by adding $10 \mathrm{ml}$ of distilled water to the leaflets, which were ground (Stomacher 80; Seward, London) for 2 min at maximum power. Every sample and appropriate dilutions were spiral plated (Spiral Biotech) on appropriate media to enumerate the inoculated strain.

We analyzed the behavior of aggregated cells and planktonic cells faced to chloroform vapors. Six independent cultures of CFBP4834-R biofilms were produced as described above in SOBG medium in glass tubes for 11 days. Cultures were then filtered on Isopore polycarbonate filters (pore diameter: $5 \mu \mathrm{m}$ ) to retain aggregated cells. Tubes were rinsed twice with sterile distilled water to remove adherent biofilms and, finally, filters were rinsed once more with sterile distilled water. The filtered suspensions were filtered on polycarbonate filters (pore diameter: $0.22 \mu \mathrm{m}$ ) to retain planktonic cells. Three filters of planktonic cells and three filters of biofilm cells were faced to chloroform vapors as described above. All 12 filters were sonicated for $2 \mathrm{~min}$ in $20 \mathrm{ml}$ of sterile distilled water at $70 \%$ sonicator amplitude with pulsations ( $1 \mathrm{~s}$ off and $2 \mathrm{~s}$ on), with an energy of sonication of $0.45 \mathrm{~W} / \mathrm{ml}$. Cell counts of every suspension were determined by dilution plating.

\section{Frequencies of transmission to seed and associated bacterial population sizes.}

Bean plants at the flower bud stage (Michael 1994) were spray inoculated until runoff with bacterial suspensions at $1 \times$ $10^{5} \mathrm{CFU} / \mathrm{ml}$. Bacterial population sizes were quantified in flower buds from five plants $3 \mathrm{~h}$ after spray inoculation and in seed from 50 plants 6 weeks after inoculation. Samples (flower buds or seed) were bulked per plant. Bulks of flower buds were weighed and ground (Stomacher 80; Seward) for 2 min at maximum power in $5 \mathrm{ml}$ of distilled water. Seed were carefully extracted from asymptomatic pods without any exogenous contamination. For that, in a sterile environment using gloves, every pod was dissected with a sterile scalpel, taking care not to touch the seed. Once the pod was opened, seed were detached one by one from the pod using sterile forceps. By this method, seed never entered into contact with the external surface of the pod or with any contaminated material. Seed were soaked overnight at $4^{\circ} \mathrm{C}$ in $2 \mathrm{ml}$ of sterile distilled water per gram of seed (5.56 seeds/g). Samples were then weighed and vigorously shaken. To quantify population sizes of mutants and to look for reversion events, aliquots of $500 \mu \mathrm{l}$ of samples and appropriate dilutions were plated on $10 \%$ TSA-rifamycin (TSA-R) or $10 \%$ TSA-R-kanamycin medium. For every sample, the identity of 10 colonies grown on $10 \%$ TSA-R was confirmed by PCR with appropriate primers (Table 1).

To compare the occurrence of the floral and vascular pathways in bacterial transmission to seed, two different inoculation methods were used. On a first set of plants, direct flower bud inoculation was performed by depositing $20 \mu \mathrm{l}$ of inoculum at $1 \times 10^{6} \mathrm{CFU} / \mathrm{ml}$ per flower bud on three groups of flower buds per plant, taking every possible precaution to avoid dispersion of the inoculum on leaves. After inoculum drying, inoculated flower buds were enclosed in transparent cellophane bags to avoid any subsequent contamination of a leaf by contact with inoculated flowers. On a second set of plants, three groups of flower buds per plant were protected 
with transparent cellophane bags before plants were inoculated by spraying the phyllosphere with inoculum at $1 \times 10^{5}$ $\mathrm{CFU} / \mathrm{ml}$. Three hours after inoculation, bacterial population sizes were quantified on leaves bulked per plant when flower buds were inoculated by depositing drops of inoculum, and on the third trifoliate leaf for spray-inoculated plants. Bacterial population sizes were also quantified in inoculated and protected flower buds. At harvest (6 weeks after inoculation), bacterial population sizes were quantified in seed extracted from pods as described above. Three plants per strain and per treatment were analyzed the day of inoculation and 10 plants per strain and per treatment at harvest. Sample analyses were performed as described above.

\section{Statistical analyses.}

Statistical analyses were performed using Statbox Pro software (Grimmer Logiciels, Optima, Mérignac, France). Logtransformed data were analyzed with Kruskal-Wallis and Mann-Whitney tests. Comparisons of transmission frequencies were based on a Pearson's $\chi^{2}$ test. To compare paired population sizes quantified on selective and nonselective media, Wilcoxon's signed-ranks test for two groups was used (Sokal and Rohlf 1969).

\section{ACKNOWLEDGMENTS}

This work was supported by a grant from the Conseil Régional des Pays de la Loire. We thank M. Arlat and E. Lauber for providing strains and mutagenesis protocol, J. Benard and P. Horeau for plant production, K. Goislot for assistance, and T. Boureau and J.-P. Paulin for critical reviews of the manuscript.

\section{LITERATURE CITED}

Altschul, S. F., Madden, T. L., Schaffer, A. A., Zhang, J., Zhang, Z., Miller, N., and Lipman, D. J. 1997. Gapped BLAST and PSI-BLAST: A new generation of protein database search programs. Nucleic Acids Res. 25:3389-3402.

Arlat, M., Gough, C. L., Barber, C. E., Boucher, C., and Daniels, M. J. 1991. Xanthomonas campestris contains a cluster of hrp genes related to the larger hrp cluster of Pseudomonas solanacearum. Mol. Plant-Microbe Interact. 4:593-601

Arlat, M., Gough, C. L., Zischek, C., Barberis, P. A., Trigalet, A., and Boucher, C. 1992. Transcriptional organization and expression of the large hrp gene cluster of Pseudomonas solanacearum. Mol. Plant-Microbe Interact. 5:187-193.

Astua-Monge, G., Freitas-Astua, J., Bacocina, G., Roncoletta, J., Carvalho, S. A., and Machado, M. A. 2005. Expression profiling of virulence and pathogenicity genes of Xanthomonas axonopodis pv. citri. J. Bacteriol. 187:1201-1205.

Barak, J. D., Gorski, P., Naraghi-Arani, P., and Charkowski, A. O. 2005. Salmonella enterica virulence genes are required for bacterial attachment to plant tissue. Appl. Environ. Microbiol. 71:5685-5691.

Barnhart, M. M., and Chapman, M. R. 2006. Curli biogenesis and function. Annu. Rev. Microbiol. 60:131-147.

Cao, H., Baldini, R. L., and Rahme, L. G. 2001. Common mechanisms for pathogens of plants and animals. Annu. Rev. Phytopathol. 39:259284.

Carbonnelle, E., Helaine, S., Nassif, X., and Pelicic, V. 2006. A systematic genetic analysis in Neisseria meningitidis defines the Pil proteins required for assembly, functionality, stabilization and export of type IV pili. Mol. Microbiol. 61:1510-1522.

Costerton, J. W., Stewart, P. S., and Greenberg, E. P. 1999. Bacterial biofilms: A common cause of persistent infections. Science 284:1318-1322.

Cotter, S. E., Surana, N. K., and St. Geme, J. W., 3rd. 2005. Trimeric autotransporters: A distinct subfamily of autotransporter proteins. Trends Microbiol. 13:199-205.

Craig, L., Pique, M. E., and Tainer, J. A. 2004. Type IV pilus structure and bacterial pathogenicity. Nat. Rev. Microbiol. 2:363-378.

Danhorn, T., and Fuqua, C. 2007. Biofilm formation by plant-associated bacteria. Annu. Rev. Microbiol. 61:401-422.

Darsonval, A., Darrasse, A., Meyer, D., Demarty, M., Durand, K., Bureau, C., Manceau, C., and Jacques, M. A. 2008. The Type III Secretion System of Xanthomonas fuscans subsp. fuscans is involved in the phyl- losphere colonization process and in transmission to seeds of susceptible beans. Appl. Environ. Microbiol. 74:2669-2678.

da Silva, A. C., Ferro, J. A., Reinach, F. C., Farah, C. S., Furlan, L. R., Quaggio, R. B., Monteiro-Vitorello, C. B., Van Sluys, M. A., Almeida, N. F., Alves, L. M., do Amaral, A. M., Bertolini, M. C., Camargo, L. E., Camarotte, G., Cannavan, F., Cardozo, J., Chambergo, F., Ciapina, L. P., Cicarelli, R. M., Coutinho, L. L., Cursino-Santos, J. R., El-Dorry, H., Faria, J. B., Ferreira, A. J., Ferreira, R. C., Ferro, M. I., Formighieri, E. F., Franco, M. C., Greggio, C. C., Gruber, A., Katsuyama, A. M., Kishi, L. T., Leite, R. P., Lemos, E. G., Lemos, M. V., Locali, E. C., Machado, M. A., Madeira, A. M., Martinez-Rossi, N. M., Martins, E. C., Meidanis, J., Menck, C. F., Miyaki, C. Y., Moon, D. H., Moreira, L. M., Novo, M. T., Okura, V. K., Oliveira, M. C., Oliveira, V. R., Pereira, H. A., Rossi, A., Sena, J. A., Silva, C., de Souza, R. F., Spinola, L. A., Takita, M. A., Tamura, R. E., Teixeira, E. C., Tezza, R. I., Trindade dos Santos, M., Truffi, D., Tsai, S. M., White, F. F., Setubal, J. C., and Kitajima, J. P. 2002. Comparison of the genomes of two Xanthomonas pathogens with differing host specificities. Nature 417:459-463.

DeFlaun, M. F., Marshall, B. M., Kulle, E. P., and Levy, S. B. 1994. Tn5 insertion mutants of Pseudomonas fluorescens defective in adhesion to soil and seeds. Appl. Environ. Microbiol. 60:2637-2642.

Devoret, R., and Blanco, M. 1970. Mutants of Escherichia coli K12 ( $\lambda)+$ non-inducible by thymine deprivation. Mol. Gen. Genet. 107:272-280.

Feil, H., Feil, W. S., and Lindow, S. E. 2007. Contribution of fimbrial and afimbrial adhesins of Xylella fastidiosa to attachment to surfaces and virulence to grape. Phytopathology 97:318-324.

Fenton, A., Fairbairn, J. P., Norman, R., and Hudson, P. J. 2002. Parasite transmission: Reconciling theory and reality. J. Anim. Ecol. 71:893905.

Finan, T. M., Kunkel, B., De Vos, G. F., and Signer, E. R. 1986. Second symbiotic megaplasmid in Rhizobium meliloti carrying exopolysaccharide and thiamine synthesis genes. J. Bacteriol. 167:66-72.

Finlay, B. B., and Falkow, S. 1997. Common themes in microbial pathogenicity revisited. Microbiol. Mol. Biol. Rev. 61:136-169.

Fislage, R., Berceanu, M., Humboldt, Y., Wendt, M., and Oberender, H. 1997. Primer design for a prokaryotic differential display RT-PCR. Nucleic Acids Res. 25:1830-1835.

Foreman-Wykert, A. K., and Miller, J. F. 2003. Hypervirulence and pathogen fitness. Trends Microbiol. 11:105-108.

Gerlach, R. G., and Hensel, M. 2007. Protein secretion systems and adhesins: The molecular armory of gram-negative pathogens. Int. J. Med. Microbiol. 297:401-415.

Gitaitis, R., and Walcott, R. 2007. The epidemiology and management of seedborne bacterial diseases. Annu. Rev. Phytopathol. 45:371-397.

Glazebrook, J., and Walker, G. C. 1991. Genetic techniques in Rhizobium meliloti. Methods Enzymol. 204:398-418.

Goel, A. K., Rajagopal, L., Nagesh, N., and Sonti, R. V. 2002. Genetic locus encoding functions involved in biosynthesis and outer membrane localization of xanthomonadin in Xanthomonas oryzae pv. oryzae. J. Bacteriol. 184:3539-3548.

Gorski, P., Palumbo, J. D., and Mandrell, R. E. 2003. Attachment of Listeria monocytogenes to radish tissue is dependent upon temperature and flagellar motility. Appl. Environ. Microbiol. 69:258-266.

Guilhabert, M. R., and Kirkpatrick, B. C. 2005. Identification of Xylella fastidiosa antivirulence genes: Hemagglutinin adhesins contribute to $X$. fastidiosa biofilm maturation and colonization and attenuate virulence. Mol. Plant-Microbe Interact. 18:856-868.

Gurlebeck, D., Thieme, F., and Bonas, U. 2006. Type III effector proteins from the plant pathogen Xanthomonas and their role in the interaction with the host plant. J. Plant Physiol. 163:233-255.

Hanahan, D. 1983. Studies on transformation of Escherichia coli with plasmids. J. Mol. Biol. 166:557-580.

Hirano, S. S., and Upper, C. D. 2000. Bacteria in the leaf ecosystem with emphasis on Pseudomonas syringae - a pathogen, ice nucleus, and epiphyte. Microbiol. Mol. Biol. Rev. 64:624-653.

Hoiczyk, E., Roggenkamp, A., Reichenbecher, M., Lupas, A., and Heesemann, J. 2000. Structure and sequence analysis of Yersinia YadA and Moraxella UspAs reveal a novel class of adhesins. EMBO (Eur. Mol. Biol. Organ.) J. 19:5989-5999.

Hultgren, S. J., Abraham, S., Caparon, M., Falk, P., St Geme, J. W., 3rd, and Normark, S. 1993. Pilus and nonpilus bacterial adhesins: Assembly and function in cell recognition. Cell 73:887-901.

International Seed Testing Association. 2007. ISTA validated method $7-$ 021: Detection of Xanthomonas axonopodis pv. phaseoli and Xanthomonas axonopodis pv. phaseoli var. fuscans on Phaseolus vulgaris. Eur. J. Plant Pathol. 119:203-215.

Jacques, M. A., Josi, K., Darrasse, A., and Samson, R. 2005. Xanthomonas axonopodis pv. phaseoli var. fuscans is aggregated in stable biofilm population sizes in the phyllosphere of field-grown beans. Appl. Environ. Microbiol. 71:2008-2015. 
Kaiser, D. 2007. Bacterial swarming: A re-examination of cell-movement patterns. Curr. Biol. 17:561-570.

Kang, Y., Liu, H., Genin, S., Schell, M. A., and Denny, T. P. 2002. Ralstonia solanacearum requires type 4 pili to adhere to multiple surfaces and for natural transformation and virulence. Mol. Microbiol. 46:427437

Kim, J. F., Ham, J. H., Bauer, D. W., Collmer, A., and Beer, S. V. 1998 The hrpC and hrpN operons of Erwinia chrysanthemi EC16 are flanked by $p l c A$ and homologs of hemolysin/adhesin genes and accompanying activator/transporter genes. Mol. Plant-Microbe Interact. 11:563-567.

Klemm, P., and Schembri, M. A. 2000. Bacterial adhesins: Function and structure. Int. J. Med. Microbiol. 290:27-35.

Koretke, K. K., Szczesny, P., Gruber, M., and Lupas, A. N. 2006. Model structure of the prototypical non-fimbrial adhesin YadA of Yersinia enterocolitica. J. Struct. Biol. 155:154-161.

Latasa, C., Solano, C., Penades, J. R., and Lasa, I. 2006. Biofilm-associated proteins. C. R. Biol. 329:849-857.

Lee, B. M., Park, Y. J., Park, D. S., Kang, H. W., Kim, J. G., Song, E. S., Park, I. C., Yoon, U. H., Hahn, J. H., Koo, B. S., Lee, G. B., Kim, H., Park, H. S., Yoon, K. O., Kim, J. H., Jung, C. H., Koh, N. H., Seo, J. S., and Go, S. J. 2005. The genome sequence of Xanthomonas oryzae pathovar oryzae KACC10331, the bacterial blight pathogen of rice. $\mathrm{Nu}-$ cleic Acids Res. 33:577-586.

Marx, C. J., and Lidstrom, M. E. 2002. Broad-host-range cre-lox system for antibiotic marker recycling in gram-negative bacteria. BioTechniques 33:1062-1067.

Matthysse, A. G., and McMahan, S. 1998. Root colonization by Agrobacterium tumefaciens is reduced in cel, attB, attD and attR mutants. Appl. Environ. Microbiol. 64:2341-2345.

Mattick, J. S. 2002. Type IV pili and twitching motility. Annu. Rev. Microbiol. 56:289-314

Maude, R. B. 1996. Seedborne diseases and their control. In: Principles \& Practice. CAB International, Oxon, UK.

Mazar, J., and Cotter, P. A. 2006. Topology and maturation of filamentous haemagglutinin suggest a new model for two-partner secretion. Mol. Microbiol. 62:641-654.

McCallum, H., Barlow, N., and Hone, J. 2001. How should pathogen transmission be modelled? Trends Ecol. Evol. 16:295-300.

Merz, A. J., So, M., and Sheetz, M. P. 2000. Pilus retraction powers bacterial twiching motility. Nature 407:98-102.

Michael, T. E. 1994. The bean plant. Pages 1-4 in: Compendium of Bean Diseases. R. Hall, ed. American Phytopathological Society Press, St. Paul, MN, U.S.A.

Newman, K., Almeida, R. P. P., Purcell, A. H., and Lindow, S. E. 2004 Cell-cell signaling controls Xylella fastidiosa interactions with both insects and plants. Proc. Natl. Acad. Sci. U.S.A. 101:1737-1742.

Ngugi, H. K., and Scherm, H. 2006. Biology of flower-infecting fungi. Annu. Rev. Phytopathol. 44:261-282.

Nummelin, H., Merckel, M. C., Leo, J. C., Lankinen, H., Skurnik, M., and Goldman, A. 2004. The Yersinia adhesin YadA collagen-binding domain structure is a novel left-handed parallel beta-roll. EMBO (Eur. Mol. Biol. Organ.) J. 23:701-711.

Ojanen-Reuhs, T., Kalkkinen, N., Westerlund-Wikstrom, B., van Doorn, J. Haahtela, K., Nurmiaho-Lassila, E. L., Wengelnik, K., Bonas, U., and Korhonen, T. K. 1997. Characterization of the fimA gene encoding bundle-forming fimbriae of the plant pathogen Xanthomonas campestris pv. vesicatoria. J. Bacteriol. 179:1280-1290.

Oke, V., and Long, S. R. 1999. Bacterial genes induced within the nodule during the Rhizobium-legume symbiosis. Mol. Microbiol. 32:837-849.

O'Toole, G., Kaplan, H. B., and Kolter, R. 2000. Biofilm formation as microbial development. Annu. Rev. Microbiol. 54:49-79.

O'Toole, G. A., and Kolter, R. 1998. Initiation of biofilm formation in Pseudomonas fluorescens WCS365 proceeds via multiple, convergent signalling pathways: A genetic analysis. Mol. Microbiol. 28:449-461.

Piper, K. R., Von Bodman, S. B., Hwang, I., and Farrand, S. K. 1999. Hierarchical gene regulatory systems arising from fortuitous gene associations: Controlling quorum sensing by opine regulon in Agrobacterium. Mol. Microbiol. 32:1077-1089.

Pizarro-Cerda, J., and Cossart, P. 2006. Bacterial adhesion and entry into host cells. Cell 124:715-727.

Pruvost, O., Savelon, C., Boyer, C., Chiroleu, F., Gagnevin, L., and Jacques, M.-A. 2008. Populations of Xanthomonas citri pv. mangiferaeindicae from asymptomatic mango leaves are primarily endophytic. Microbial Ecol. doi:10.1007/s00248-008-9480-x. Published online.

Puhler, A., Arlat, M., Becker, A., Gottfert, M., Morrissey, J. P., and O'Gara F. 2004. What can bacterial genome research teach us about bacteriaplant interactions? Curr. Opin. Plant Biol. 7:137-147.
Qian, W., Jia, Y., Ren, S. X., He, Y. Q., Feng, J. X., Lu, L. F., Sun, Q Ying, G., Tang, D. J., Tang, H., Wu, W., Hao, P., Wang, L., Jiang, B. L. Zeng, S., Gu, W. Y., Lu, G., Rong, L., Tian, Y., Yao, Z., Fu, G., Chen, B., Fang, R., Qiang, B., Chen, Z., Zhao, G. P., Tang, J. L., and He, C. 2005. Comparative and functional genomic analyses of the pathogenicity of phytopathogen Xanthomonas campestris pv. campestris. Genome Res. 15.

Ray, S. K., Rajeshwari, R., Sharma, Y., and Sonti, R. V. 2002. A high-molecular-weight outer membrane protein of Xanthomonas oryzae pv. oryzae exhibits similarity to non-fimbrial adhesins of animal pathogenic bacteria and is required for optimum virulence. Mol. Microbiol. 46:637-647.

Roine, E., Raineri, D. M., Romantschuk, M., Wilson, M., and Nunn, D. N. 1998. Characterization of type IV pilus genes in Pseudomonas syringae pv. tomato DC3000. Mol. Plant-Microbe Interact. 11:1048-1056.

Rojas, C. M., Ham, J. H., Deng, W. L., Doyle, J. J., and Collmer, A. 2002. $\mathrm{Hec} \mathrm{A}$, a member of a class of adhesins produced by diverse pathogenic bacteria, contributes to the attachment, aggregation, epidermal cell killing, and virulence phenotypes of Erwinia chrysanthemi EC16 on Nicotiana clevelandii seedlings. Proc. Natl. Acad. Sci. U.S.A. 99:1314213147.

Rosenblueth, M., and Martinez-Romero, E. 2006. Bacterial endophytes and their interactions with hosts. Mol. Plant-Microbe Interact. 19:827-837.

Schaad, N. W., Postnikova, E., Lacy, G. H., Sechler, A., Agarkova, I., Stromberg, P. E., Stromberg, V. K., and Vidaver, A. K. 2005. Reclassification of Xanthomonas campestris pv. citri (ex Hasse 1915) Dye 1978 forms $\mathrm{A}, \mathrm{B} / \mathrm{C} / \mathrm{D}$, and $\mathrm{E}$ as $X$. smithii subsp. citri (ex Hasse) sp. nov. nom. rev. comb. nov., X. fuscans subsp. aurantifolii (ex Gabriel 1989) sp. nov. nom. rev. comb. nov., and $X$. alfalfae subsp. citrumelo (ex Riker and Jones) Gabriel et al., 1989 sp. nov. nom. rev. comb. nov.; X. campestris pv malvacearum (ex Smith 1901) Dye 1978 as X. smithii subsp. smithii nov. comb. nov. nom. nov.; X. campestris pv. alfalfae (ex Riker and Jones, 1935) Dye 1978 as X. alfalfae subsp. alfalfae (ex Riker et al., 1935) sp. nov. nom. rev.; and "var. Fuscans" of X. campestris pv. phaseoli (ex Smith, 1987) Dye 1978 as X. fuscans subsp. fuscans sp. nov. Syst. Appl. Microbiol. 28:494-518.

Sokal, R. R., and Rohlf, F. J. 1969. Biometry. The Principles and Practice of Statistics in Biological Research. W. H. Freeman \& Co., San Francisco.

Stockwell, V. O. 2005. Flowers: Diverse and mutable microbial habitats. (Abstr.) Phytopathology 95:S128.

Thieme, F., Koebnik, R., Bekel, T., Berger, C., Boch, J., Buttner, D., Caldana, C., Gaigalat, L., Goesmann, A., Kay, S., Kirchner, O., Lanz, C., Linke, B., McHardy, A.C., Meyer, F., Mittenhuber, G., Nies, D. H., Niesbach-Klosgen, U., Patschkowski, T., Ruckert, C., Rupp, O., Schneiker, S., Schuster, S. C., Vorholter, F. J., Weber, E., Puhler, A., Bonas, U., Bartels, D., and Kaiser, O. 2005. Insights into genome plasticity and pathogenicity of the plant pathogenic bacterium Xanthomonas campestris pv. vesicatoria revealed by the complete genome sequence. J. Bacteriol. 187:7254-7266.

Tobe, T., and Sasakawa, C. 2002. Species-specific cell adhesion of enteropathogenic Escherichia coli is mediated by type IV bundle-forming pili. Cell Microbiol 4:29-42.

van Doorn, J., Hollinger, T. C., and Oudega, B. 2001. Analysis of the type IV fimbrial-subunit gene fimA of Xanthomonas hyacinthi: Application in PCR-mediated detection of yellow disease in Hyacinths. Appl. Environ. Microbiol. 67:598-607.

Vauterin, L., Hoste, B., Kersters, K., and Swings, J. 1995. Reclassification of Xanthomonas. Int. J. Syst. Bacteriol. 45:472-489.

Vauterin, L., Rademaker, J., and Swings, J. 2000. Synopsis on the taxonomy of the genus Xanthomonas. Phytopathology 90:677-682.

Vidaver, A. K. 1993. Xanthomonas campestris pv. phaseoli: Cause of common bacterial blight of bean. Pages 40-44 in: Xanthomonas. J. G. Swings and E. L. Civerolo, eds. Chapman \& Hall, London.

West, S. A., Griffin, A. S., Gardner, A., and Diggle, S. P. 2006. Social evolution theory for microorganisms. Nat. Rev. Microbiol. 4:597-607.

Yap M.-N., Yang, C.-H., Barak, J. D., Jahn, C. E., and Charkowski, A. O. 2005. The Erwinia chrysanthemi type III secretion system is required for multicellular behavior. J. Bacteriol. 187:639-648

\section{AUTHOR-RECOMMENDED INTERNET RESOURCES}

NCBI BLAST webpage: www.ncbi.nlm.nih.gov/blast/Blast.cgi

EMBL-European Bioinformatics Institute (EBI) ClustalW2 webpage: www.ebi.ac.uk/Tools/clustalw2

EMBL-EBI InterProScan sequence search webpage: www.ebi.ac.uk/InterProScan 